\title{
Biopreservative application of bacteriocins obtained from samples Ictalurus punctatus and fermented Zea mays
}

\author{
Oyinlade C. Ogundare ${ }^{1^{*}}$, Simeon K. Odetunde ${ }^{1}$, Mutiat A. Omotayo ${ }^{1}$, Oluremilekun 0. \\ Sokefun', Rasheed O. Akindiya' and Adetayo Akinboro ${ }^{2}$ \\ ${ }^{1}$ Department of Chemical Science, School of Pure and Applied Science, Lagos State Polytechnic, Ikorodu, PMB 21606, \\ Ikeja, Lagos State, Nigeria. \\ ${ }^{2}$ Department of Biochemistry, Faculty of Basic Medical Sciences, Ladoke Akintola University of Technology, Ogbomoso, \\ Oyo State, Nigeria.
}

Received 12 January, 2017; Accepted 7 April, 2021

This study evaluated the preservative ability of protein-like cell free supernatants produced by lactic acid bacteria (LAB) isolates from samples of Ictalurus punctatus (Cat fish) and slurry of fermented Zea mays (Ogi). The LAB strains were separately isolated from understudied samples using De Man, Rogosa and Sharpe (MRS) media at $37^{\circ} \mathrm{C}$ for $48 \mathrm{~h}$. The isolated strains were characterized with Gram staining, oxidase and catalase tests, microscopy study, carbohydrate fermentation, acid production and $\mathrm{NaCl}$ tolerance. Thereafter, the protein concentrations of crude bacteriocin supernatants from the Gram positive, rod shaped, oxidase and catalase negative strains were studied. Also, the growth inhibition of Bacillus subtilis, Staphyloccocus aureus and Escherichia coli, heat stability, pH tolerance, effect of proteolytic enzyme and biopreservation efficiency of protein-like cell free supernatants (crude bacteriocins) were determined. Biopreservative efficiency of the crude bacteriocin samples was also determined in orange (Citrus sinenses) and Titus fish (Scomber scombrus). The isolates from intestine of $I$. punctatus and fermented $Z$. mays fermented carbohydrate, and grew optimally at $3 \% \mathrm{NaCl}$, and 10 and $37^{\circ} \mathrm{C}$, respectively. They inhibited the multiplication of $E$. coli at various extents, but more effective on different strains. The bacteriocins from slurry of fermented $Z$. mays on the other hand, were more potent in $E$. coli $(22.7 \pm 0.8 \mathrm{~mm})$ than $S$. aureus $(7.9 \pm 0.1 \mathrm{~mm})$. The biopreservative efficiency of crude bacteriocin from I. punctatus was greater than that of Z. mays. The LAB obtained from the selected samples produced protein-like substances in form of bacteriocins with potent antibacterial and biopreservative proficiencies through the growth inhibition of tested pathogens and low colony counts on tested food samples, respectively. Bacterial isolates obtained from samples of $I$. punctatus and $Z$. mays can be successfully used in the preservation of food and vegetables.

Key words: Ictalurus punctatus, Zea mays, bacteriocin, protein-like substances, biopreservative ability.

\section{INTRODUCTION}

Ictalurus punctatus and fermented Zea mays are parts of the many functional foods that are consumed in West African countries, and are produced through the use of lactic acid bacteria ( $\mathrm{LAB}$ ) during metabolism or production processes. For instance, several LAB strains have been isolated and established from grain products, dairy products, meat and fish products, beer and wine, fruit and its fruit juices, pickled vegetables and mash foods, as 
well as during fermentation of plant materials (Liu et al., 2014)

I. punctatus (Channel Catfish) is a fresh water fish and commonly used as one of the protein sources in African diets. It is widely known as 'Eja aro' in western part of Nigeria. The demand for $l$. punctatus has grown significantly in the recent years (Eun et al., 1994). Like any other aquatic animals, the GIT or gut of $I$. punctatus contains series of bacteria which include $L A B$ or compounds obtained from LAB (bacteriocins, organic acid and many more), and these candidates are known for probiotic activity against both Gram-positive or negative pathogens (Ringø and Gatesoupe, 1998). Moreover, the presence of probiotic LAB or their products in aquatic animals converses immunity to the animals (Behnsenet al., 2013; Shahid et al., 2017).

Fermented Z. mays is commonly called Ogi, Pap, Koko and Akamu in different parts of Nigeria. It is taken by both children and adults, and can be processed to give different products. Fermented $Z$. mays is obtained by fermentation of maize in the presence of $L A B$ leading to improvement of nutritional and sensory properties, and shelf life of the fermented $Z$. mays (Adesokan et al., 2010; Ejigui et al., 2005; ljarotimi and Keshinro, 2011).

In the fermentation of $Z$. mays, two fermentation procedures are applied; natural fermentation in which raw clean Z. mays are allowed to ferment naturally by steeping in water at room temperature for a period of 12 to $72 \mathrm{~h}$, and artificial fermentation in which $Z$. mays are exposed to $L A B$ and anti-fungi agents in the presence of water for a period of 12 to $48 \mathrm{~h}$ (Alka et al., 2012; Ogodo et al., 2017).

$L A B$, which are naturally part of the microbial flora that are present in foods such as $Z$. mays or during steeping in the present inoculum during artificial fermentation encourages fermentation via rapid acidification of the food matrix and enhances food safety or production of antimicrobial metabolites, which create a physicochemical environment that prevents the growth of potential spoilage and pathogenic organism, improves food texture, nutritional value, and aroma (Smid and Kleerebezem, 2014).

The benefits of $L A B$ cannot be overemphasized, $L A B$ being part of the component of daily food materials such as poultry, fish, dairy and meat products, may enhance appropriate equilibrium in the intestinal flora, improved digestion of lactose, control serum cholesterol and certain types of cancer (Ali, 2010; Udhayashree et al., 2012). The LAB strains are used as starter culture for important biological processes including fermentation, aroma production, as well as microbiological stability (De Vuyst and Leroy, 2007; du Toit et al., 2011; Smid and Kleerebezem, 2014; Trząskowska et al., 2014).
Microbiological stability of food samples in the presence of LAB is achieved by liberation of antimicrobial substances (organic acids, diacetyl, hydrogen peroxide and bacteriocins), and has been reportedly responsible for food preservation (Vignolo et al., 2012; Yang et al., 2014). Reports showed that the addition of antimicrobial substances (bacteriocins) to foods may not pose risks to the consumer's health or affect the nutritional and sensory quality of the food (Vignolo et al., 2012; Woraprayote et al., 2016).

Perez et al. (2014) described bacteriocins as heat stable antimicrobial peptides or proteinaceous compounds that are synthesized in the ribosomes by LAB strains which are naturally found in foods, and are effective in inhibiting the growth of similar or closely related bacterial strains from fermented foods without affecting the producing strain (Ramu et al., 2015). A recent report showed that the peptide compounds are effective on Gram-positive bacteria, and numerous food-borne and pathogenic microorganisms (Barbosa et al., 2017). Although bacteriocins may be sensitive to certain proteolytic enzymes, temperature and $\mathrm{pH}$, their application in food preservation is generally regarded as safe and known to enhance the sensory qualities of the food samples and extend their shelf life (Chang and Chang, 2010; Reis et al., 2012). Therefore, bacteriocins are exploited in food preservation (Del Nobile et al., 2012; Silva et al., 2018). The LAB bacteriocins function by different mechanisms in order to exercise their antimicrobial activity (Deegan et al., 2006). It involves the leakage of proteins, alteration of cell membrane integrity, DNA and RNA (Gould, 2012; Lee and Kim, 2011). Recently, as a result of the safe potency of origins of bacteriocins and extensive scope of efficacy of the peptide substance on pathogenic organisms, attention of researchers has been placed on the use bacteriocins in inhibition of pathogenic organisms in foods, and then application in industrial food preservation (Ghanbari et al., 2013).

The use of preservatives in food safety has been one of the major ways by which foods are made available at all seasons, as their shelf lives are extended via protection of foods from chemical, physical and microbiological alterations that cause food spoilage (Yousef and Balasubramaniam, 2013). Methods involving physical and chemical processes using natural (preservatives obtained from plants, animals or microorganisms) or artificial (synthetic compounds) preservatives are employed in preservation to destroy, remove or inhibit the growth of unwanted microorganisms (Farkas, 2007; Gould, 2012; Lück, 1985). Natural process like drying or roasting is used to kill or reduce the levels of food poisoning causing microorganisms in food products.

${ }^{*}$ Corresponding author. E-mail: ogundareoyinlade@yahoo.com.

Author(s) agree that this article remain permanently open access under the terms of the Creative Commons Attribution License 4.0 International License 
These methods alter the colour of foods, while many of the chemical preservation methods are limited due their side effects. Nitrates, benzoic acid or its salts, formaldehyde, sorbates, parabens, butylated hydroxyl toluene (BHA), and butylated hydroxy anisole (BHA) are responsible for serious health perils such as hypersensitivity, asthma, allergy, cancer, hyperactivity and neurological damage of consumers (Shahidi, 2015; Sharma, 2015). Of all these preservatives, the most commonly used artificial preservative is benzoic acid. Aside from drying and roasting, antioxidant and antimicrobial agents are exploited in the prevention of food spoilage, and increase shelf life of foods and vegetables. These compounds include antioxidant such as vitamins $\mathrm{C}$ and $\mathrm{E}$, and antimicrobial: bacteriocin (Davidson et al., 2012). The antioxidant forms of preservative are known to generate free radicals especially when used at a relatively high dosage (Piper et al., 2001).

Summarily, the currently applied methods of food preservative (physical and chemical methods) are limited as a result of the consumer needs for safe and minimally processed foods. The associated limitations have led to recent researches in the production bio-preservatives such bacteriocins. Although, the use of bacteriocins from LAB strains have been previously reported by scientists, but to the best of our knowledge there has been paucity of data as regard the production of proteinaceous bacteriocin produced by $L A B$ isolates obtained from samples of $I$. punctatus and the slurry of fermented $Z$. mays. Therefore, this study attempts to produce and characterize and investigate antibacterial potential of proteinaceous substances from the understudied food sample. Moreover, the bio-preservative activity of the suspected bacteriocins was established against pathogens associated with samples of Titus fish and orange juice.

\section{MATERIALS AND METHODS}

\section{Collection of samples for analysis}

A total of six (6) samples of life $I$. punctatus were randomly collected from nearby Fish-farm in Ikorodu, Lagos State and taken to the laboratory in a cellophane bag containing small quantity of clean water. In the laboratory, the samples of fish were sacrificed, and the obtained intestine was stored at $4^{\circ} \mathrm{C}$ for about $2 \mathrm{~h}$ in readiness for analysis. The slurries of fermented $Z$. mays samples were also collected from nearby local producers, stored in ice bath and taken to the laboratory for instant use.

\section{Isolation and identification of bacteriocin producing organisms}

The collected samples of $I$. punctatus were cut and their intestines rinsed in normal saline. The intestines $(1.0 \mathrm{~g})$ were taken from each I. punctatus and pulverized to paste in normal saline $(10 \mathrm{~mL})$ by use of mortar and pestle to give stock solution of $0.1 \mathrm{~g} \mathrm{sample} / \mathrm{mL}$. Similarly, slurry sample $(1.0 \mathrm{~g})$ of fermented $Z$. mays was also taken into clean mortal and pulverized to paste in normal saline $(10 \mathrm{~mL})$ by use of mortar and pestle to give stock solution of $0.1 \mathrm{~g}$ sample/mL. Homogenate of the intestine of $l$. punctatus or fermented $Z$. mays was centrifuged at $5000 \mathrm{rpm}$ for $10 \mathrm{~min}$ to obtain the supernatant. The supernatants obtained from samples of intestine of $I$. punctatus or fermented $Z$. mays were combined to give homogenates of intestine of $I$. punctatus or fermented $Z$. mays, respectively. A measure $(10 \mathrm{~mL})$ of each supernatant was taken into a conical flask and carefully inoculated into freshly prepared de Man, Rogosa (MRS) broth $(40 \mathrm{~mL})$ in order to isolate the possible $\mathrm{LAB}$ isolates. The culture was in turn distributed into $10 \mathrm{~mL}$ sterilized test tubes and incubated at $37^{\circ} \mathrm{C}$ for 2 days with persistent shaking on a shaker under anaerobic situations. Every tube exhibiting turbidity was chosen, and further inoculated onto MRS agar plates and incubated for 2 days at $37^{\circ} \mathrm{C}$ under anaerobic conditions.

Possible LAB plates (plates showing creamy or white colonies) were selected, and further purified for two successful times by aseptically streaking the organisms on MRS agar plates so as to increase the number of pure bacteria. The resulting creamy or white cultures that were established by Gram staining using crystal violet dye, oxidase test trips, cell morphology by examination on microscope and catalase test were branded as LAB. The plates containing pure $L A B$ colonies were stored in the refrigerator for further studies. Additionally, the LAB isolates were further identified by the following assays.

\section{Fermentation of carbohydrates by $L A B$ isolates}

Ability to ferments carbohydrate by use of protocol of Tserovska et al. (2002) was adopted with slight modifications. MRS broth (medium containing $1 \mathrm{~g}$ beef extract, $10 \mathrm{~g}$ protease peptone No. 3 , $5 \mathrm{~g}$ yeast extract, $2 \mathrm{~g} \mathrm{~K}_{2} \mathrm{HPO}_{4}, 5 \mathrm{~g} \mathrm{CH} \mathrm{CHONa}_{3} 3 \mathrm{H}_{2} \mathrm{O}, 5 \mathrm{~g}$ sodium chloride, $0.2 \mathrm{~g} \mathrm{MgSO}_{4}, 0.05 \mathrm{~g} \mathrm{MnSO}_{4}, 0.17 \mathrm{~g}$ phenol red and $1 \mathrm{~mL}$ of tween 80 ) was prepared in distilled water. The aforementioned solution was filtered and used as solvent for preparation of $1 \%$ sugar solution (carbon source), this is an orange coloured carbohydrate broth, $\mathrm{pH} 7.4$. The carbohydrate broth $(5 \mathrm{~mL})$ was poured into $10 \mathrm{~mL}$ test tube and Durham tube was inserted into it so as to detect gas production. The tube was then autoclaved at $121^{\circ} \mathrm{C}$ for $15 \mathrm{~min}$ for glucose, and $121^{\circ} \mathrm{C}$ for $3 \mathrm{~min}$ for lactose, maltose or sucrose. The LAB isolates were aseptically inoculated by use of inoculating loop into different test tubes, and incubated for $37^{\circ} \mathrm{C}$. A pronounced air bubble in the Durham tube after $48 \mathrm{~h}$ indicates fermentation of sugar with gas production, and lack of gas bubble indicates that fermentation did not occur.

\section{Acid production by $L A B$ isolates}

The reaction tubes that have been subjected to fermentation were further studied for acid production. Acid production by the isolates was characterized by the change in the orange colour of the solution in the test tube to yellow colouration as a result of production of acid by the lactic acid bacteria.

\section{Heat tolerance test}

The ability of the isolates to grow at various temperatures was investigated by use of Kozaki et al. (1992) method. Pure colonies of $\mathrm{LAB}$ isolates were aseptically obtained from MRS agar plates, and inoculated into tubes containing MRS broth. Tubes were incubated in anaerobic jars at temperatures of $10,27,37$ and $50^{\circ} \mathrm{C}$ for $48 \mathrm{~h}$. Positive results were determined as formation of turbid or cloud solution. Heat tolerance was monitored following the streaking of 1 $\mathrm{mL}$ of broth on sterile MRS agar plates. This was incubated at $37^{\circ} \mathrm{C}$ for a period of $48 \mathrm{~h}$. 


\section{$\mathrm{NaCl}$ tolerance}

MRS broth $(10 \mathrm{~mL})$ containing 3, 5, 7 and $9 \%(\mathrm{w} / \mathrm{w}) \mathrm{NaCl}$ was prepared into different test tubes and sterilized (Zou et al., 2013). $\mathrm{LAB}$ isolates were inoculated into the MRS broth and incubated at $37^{\circ} \mathrm{C}$ for $48 \mathrm{~h}$. Test tubes were visualized in order to monitor the growth based on turbidity of the resulting broth. $\mathrm{NaCl}$ tolerance was evaluated following the streaking of $1 \mathrm{~mL}$ of broth on sterile MRS agar plates. This was incubated at $37^{\circ} \mathrm{C}$ for a period of $48 \mathrm{~h}$. Tubes containing $\mathrm{LAB}$ cultures without $\mathrm{NaCl}$ served as positive control.

\section{Production of crude bacteriocins}

Gram positive, cocci-shaped organisms, which are found to be oxidase and catalase negative isolates (purified LAB), were inoculated into MRS broth at $37^{\circ} \mathrm{C}$ for 2 days to obtain bacteriocin as more $\mathrm{LAB}$ isolates are produced. At the expiration of fermentation, cells were harvested by centrifugation at $30000 \mathrm{rpm}$ for $15 \mathrm{~min}$. Denaturation was prevented by maintaining temperature range of 2 to $4^{\circ} \mathrm{C}$ in an ice bath. The resulting cell free supernatant were tested for protein which was quantified by use of Lowry's method (Lowry, 1951). These were reserved as the crude bacteriocin samples.

\section{Determination of protein concentration}

The concentrations of protein in crude bacteriocins obtained from $\mathrm{LAB}$ isolates from intestines of $l$. punctatus and slurries of fermented $Z$. mays were determined according to Lowry's method (Lowry, 1951). Briefly, a set of nine test tubes containing $0.5 \mathrm{~mL}$ of standard bovine serum albumin (BSA) solutions of concentration ranging from 0 to $2 \mathrm{mg} / \mathrm{mL}$ were prepared as standard from a stock BSA ( $4 \mathrm{mg} / \mathrm{mL})$ solution, and used to prepare a standard curve. The bacteriocins were also dispensed into different test tubes. The standard or sample of bacteriocins $(0.1 \mathrm{~mL})$ was separately mixed with $0.1 \mathrm{~mL}$ of $2 \mathrm{~N} \mathrm{NaOH}$. These were hydrolyzed at $100^{\circ} \mathrm{C}$ for 10 min in a boiling water bath and cooled to room temperature. Additionally, $1 \mathrm{~mL}$ of freshly prepared complex-forming reagent prepared from a mixture of solutions of $2 \%(\mathrm{w} / \mathrm{v}) \mathrm{Na}_{2} \mathrm{CO}_{3}, 1 \%(\mathrm{w} / \mathrm{v})$ $\mathrm{CuSO}_{4} .5 \mathrm{H}_{2} \mathrm{O}$ and $2 \%(\mathrm{w} / \mathrm{v})$ sodium potassium tartrate in ratio 100:1:1 was added. The reaction mixtures were incubated at room temperature for $40 \mathrm{~min}$ and their absorbance values were read at $550 \mathrm{~nm}$. The analysis was done in triplicates and the protein concentration of the bacteriocins obtained from standard curve.

\section{Antimicrobial activity of crude bacteriocins}

Antimicrobial activities of bacteriocins against three common pathogenic microorganisms (Escherichia coli, Staphylococcus aureus and Bacillus subtilis) were determined by well diffusion method under anaerobic condition. The activity was considered according to the extent of growth of the test organisms as bactericidal (where there is no growth of the organism in the presence of the bacteriocin) or bacteriostatic (inhibitory activity). Summarily, inoculum of test organisms $\left(1 \times 10^{5} \mathrm{CFU} / \mathrm{mL}\right)$ was introduced into freshly prepared nutrient agar plates. This was spread over the plates using swab sticks and four wells $(8 \mathrm{~mm})$ were bored into each plate before $20 \mu \mathrm{l}$ of crude bacteriocin (cell free supernatant) was introduced into each well. The plates were incubated at the $37^{\circ} \mathrm{C}$ [optimum temperature for indicator microorganisms as documented in previous reports (Noor et al., 3013; Stewart, 2003; Hanim, 2017)] for $24 \mathrm{~h}$. The antimicrobial activity of crude bacteriocins was determined by measuring diameter of clear zone around each well. Values were expressed as mean of triplicate readings.

\section{Heat stability of crude bacteriocins}

Protocol of Udhayashree et al. (2012) was adopted with slight modification. A measure of $5 \mathrm{~mL}$ of crude bacteriocins in different test tubes was heated at $10,37,50,80$ and $90^{\circ} \mathrm{C}$ for a period of $2 \mathrm{~h}$ under pressure. The heat treated bacteriocin samples were then studied for antimicrobial activity on the indicator organisms for which the bacteriocin was bactericidal by use of well diffusion method.

\section{Effect of $\mathrm{pH}$ on crude bacteriocins}

Aliquot of crude bacteriocins $(5 \mathrm{~mL})$ was taken in test tubes and the $\mathrm{pH}$ of the contents was separately regulated at $\mathrm{pH} 2,4,6,7$ and 9, using either $1 \mathrm{M}$ solution of $\mathrm{HCl}$ or $\mathrm{NaOH}$. The tubes and their contents were left at room temperature for $2 \mathrm{~h}$ and assessed for antimicrobial activity by use of well diffusion method (Udhayashree et al., 2012).

\section{Effect of trypsin on crude bacteriocins}

Indicator organism that was selected here was E. coli. Aliquot of crude bacteriocins $(5 \mathrm{~mL})$ was taken into test tubes and treated with trypsin $(1 \mathrm{mg} / \mathrm{mL})$ at optimum $\mathrm{pH}$ for the bacteriocin substance $(\mathrm{pH}$ 7 ). The control contained no enzyme, but $5 \mathrm{~mL}$ of phosphate buffer and bacteriocin. Test tubes and their contents were incubated at $37^{\circ} \mathrm{C}$ for $2 \mathrm{~h}$ and heated at $100^{\circ} \mathrm{C}$ for $3 \mathrm{~min}$ to denature the enzyme. Both the control and samples were studied for antimicrobial activity using well diffusion method according to protocol of Udhayashree et al. (2012).

\section{Biopreservative efficiency of bacteriocins}

Healthy ripe oranges (Citrus sinenses) obtained from a nearby market were washed, peeled, cut into pieces and pressed on juice extractor. The extract obtained was filtered using filter paper to separate the juice from the orange insoluble fiber. The orange juice was stored in a clean sample bottles at $4^{\circ} \mathrm{C}$ for further use.

Fresh Titus fish (Scomber scombrus) were obtained from nearby market, the flesh was removed and ground in mortal in a measure of $100 \mathrm{~g}$ Titus fish to $1 \mathrm{~L}$ of $3 \% \mathrm{NaCl}$ solution so as to obtain a $10 \%$ fish homogenate. The homogenate was then stored at $4^{\circ} \mathrm{C}$ in the refrigerator until analysis. The selected sample solutions were sterilized in an autoclave at $72^{\circ} \mathrm{C}$ for $2 \mathrm{~min}$. In other to compare the biopreservative ability of the bacteriocins with a chemical preservative, benzoic acid was used as a standard. The assessment was done according to the protocol of Pratush et al. (2012). Briefly, inoculum of $E$. coli $\left(8.5 \times 10^{5} \mathrm{CFU} / \mathrm{mL}\right)$ was introduced to three sets of sterilized glass bottles labelled as Control, Standard and Sample that contain $100 \mathrm{~mL}$ of either orange juice or fish homogenate. This was followed by addition of sodium benzoate at a concentration of $600 \mathrm{mg} / \mathrm{mL}$ to the Standard, while the Sample was treated with only crude bacteriocin at $600 \mathrm{mg} / \mathrm{mL}$. The test samples were incubated at $37^{\circ} \mathrm{C}$ for seven days and their microbial counts were monitored daily. The experiment was done in triplicates.

\section{Statistical analysis}

Statistical analysis of bacterial growth was achieved by use of comparison at $\mathrm{P}<0.05$ value through Turkey test with the aid of GraphPad Prism (version 5.01). Standard deviations for all the analyzed data are indicated by error bars. 
Table 1. Characteristics of isolates from intestine of $I$. punctatus and slurry of fermented $Z$. mays.

\begin{tabular}{|c|c|c|}
\hline Test & Intestine of I. punctatus & Fermented Z. mays \\
\hline Growth in MRS broth & Consistent turbidity & Consistent turbidity \\
\hline Number of colonies on MRS agar & 8 smooth round colonies & 17 smooth round colonies \\
\hline Colony morphology & Cream or white coloured rod organisms & Bright white coloured rod organisms \\
\hline Gram staining & Gram positive non-spore forming & Gram positive non-spore forming \\
\hline Catalase test & Negative & Negative \\
\hline Oxidase test & Negative & Negative \\
\hline Acid production during glucose fermentation & Yes & Yes \\
\hline Glucose fermentation & Gas production & Gas production \\
\hline Fructose fermentation & Gas production & Gas production \\
\hline Maltose fermentation & Gas production & Gas production \\
\hline Lactose fermentation & Gas production & Gas production \\
\hline \multicolumn{3}{|l|}{ Heat tolerance } \\
\hline Growth at $10 \stackrel{\circ}{\mathrm{C}}$ & Yes & Yes \\
\hline Growth at $27 \stackrel{\circ}{\mathrm{C}}$ & Yes & Yes \\
\hline Growth at $37^{\circ} \mathrm{C}$ & Yes & Yes \\
\hline Growth at $50 \stackrel{\circ}{C}$ & No & No \\
\hline \multicolumn{3}{|l|}{$\mathrm{NaCl}$ tolerance } \\
\hline Growth in $3 \% \mathrm{NaCl}$ & Yes & Yes \\
\hline Growth in $5 \% \mathrm{NaCl}$ & Yes & No \\
\hline Growth in $7 \% \mathrm{NaCl}$ & No & No \\
\hline Growth in $9 \% \mathrm{NaCl}$ & No & No \\
\hline
\end{tabular}

Table 2. Protein concentrations of bacteriocin like substance from intestine of $I$. punctatus and slurry of fermented Z. mays.

\begin{tabular}{lcc}
\hline Test & Intestine of $\boldsymbol{l}$. punctatus & Fermented Z. mays \\
\hline Protein concentrations & $108.4 \pm 3.9 \mathrm{mg} / \mathrm{mL}$ & $102.7 \pm 3.0 \mathrm{mg} / \mathrm{mL}$ \\
\hline
\end{tabular}

\section{RESULTS}

Selection of potential probiotic requires proper identification of the selected organism through morphological, biochemical and most times genotypic characterization (Pham et al., 2014). In the present study, morphological and biochemical properties of LAB isolates from intestine of $I$. punctatus and slurry of fermented $Z$. mays (Table 1) revealed the presence of eight (8) white colour rod shaped micro-organisms in intestine of $I$. punctatus compared to the seventeen (17) that were found in slurry of fermented $Z$. mays. These organisms appeared white in colour. Furthermore, biochemical characterization of the isolated microorganisms showed that there was no liberation of $\mathrm{O}_{2}$ in the presence of $\mathrm{H}_{2} \mathrm{O}_{2}$, neither was there a change in the colour of the strip of paper (purple) during oxidase test by use of Kovács oxidase reagent. The isolated organisms liberated acid and gas from glucose during fermentation, and produced gas in the fermentation of other carbohydrates (fructose, maltose and lactose). Table 1 also illustrates the heat and salt (sodium chloride) tolerance capacity of the isolates. The strains were able to grow between 10 and $37^{\circ} \mathrm{C}$ and tolerated at least $3 \% \mathrm{NaCl}$ concentration.

Table 2 reveals that the cell free supernatant obtained from cultures of $L A B$ isolates from intestine of $l$. punctatus and slurry of fermented $Z$. mays contained $108.4 \pm 3.91$ and $102.7 \pm 3.0 \mathrm{mg} / \mathrm{mL}$ crude protein, respectively. The proteinaceous supernatants inhibited growth of E. coli, S. aureus and B. subtilis at varied capacity (Table 3 ) as shown by the diameter of the circle that is formed around the diameter of the cork borer (was used for the well) as a result of the inhibitory activity of proteinaceous supernatants (crude bacteriocins) against indicator organisms. The crude bacteriocin from the isolates from intestine of $I$. punctatus was more potent on B. subtilis $(26.0 \pm 0.9 \mathrm{~mm})$ than E. coli $(8.1 \pm 0.31 \mathrm{~mm})$, but did not inhibit the growth of $S$. aureus at all. The bacteriocin from slurry of fermented $Z$. mays on the other hand, was more potent on $E$. coli $(22.7 \pm 0.8 \mathrm{~mm})$ unlike 
Table 3. Antimicrobial activity of crude bacteriocins from intestine of $I$. punctatus and slurry of fermented $Z$. mays.

\begin{tabular}{lcc}
\hline \multirow{2}{*}{ Indicator organism } & \multicolumn{2}{c}{ Zones of inhibition of bacteriocin $(\mathrm{mm})$} \\
\cline { 2 - 3 } & Intestine of l. punctatus & Fermented Z. mays \\
\hline E. coli & $8.1 \pm 0.3$ & $22.7 \pm 0.8$ \\
S. aureus & No inhibition & $7.9 \pm 0.1$ \\
B. subtilis & $26.0 \pm 0.9$ & No inhibition \\
\hline
\end{tabular}

Table 4. Effect of temperature on the inhibitory activities of crude bacteriocins from intestine of $I$. punctatus and slurry of fermented $Z$. mays.

\begin{tabular}{lccc}
\hline \multirow{2}{*}{ Indicator organisms } & $\begin{array}{c}\text { Temperature } \\
(\mathbf{0} \mathbf{C})\end{array}$ & \multicolumn{2}{c}{ Zones of inhibition of bacteriocin (mm) } \\
\cline { 3 - 4 } & 10 & $7.60 \pm 0.3$ & $17.10 \pm 0.2$ \\
& 37 & $7.50 \pm 1.0$ & $22.00 \pm 0.2$ \\
E. coli & 50 & $10.10 \pm 0.2$ & $19.50 \pm 1.8$ \\
& 80 & $2.30 \pm 0.1$ & $5.30 \pm 0.2$ \\
& 90 & No inhibition & No inhibition \\
S. aureus & 10 & No inhibition & $2.40 \pm 0.01$ \\
& 37 & No inhibition & $7.10 \pm 0.21$ \\
& 50 & No inhibition & $6.00 \pm 0.05$ \\
& 80 & No inhibition & No inhibition \\
& 90 & No inhibition & No inhibition \\
B. subtilis & 10 & $16.0 \pm 0.3$ & No inhibition \\
& 37 & $26.1 \pm 0.1$ & No inhibition \\
& 50 & No inhibition & No inhibition \\
& 80 & No inhibition & No inhibition \\
& 90 & No inhibition & No inhibition \\
\hline
\end{tabular}

the inhibition of $S$. aureus $(7.9 \pm 0.1 \mathrm{~mm})$.

Effects of temperature (Table 4) and $\mathrm{pH}$ (Table 5) revealed that the crude isolated bacteriocins were optimally stable at 37 and $50^{\circ} \mathrm{C}$ for bacteriocins from fermented $Z$. mays and intestine of $I$. punctatus, respectively, and $\mathrm{pH} 6$ to 7 , respectively against selected indicator organisms. The inhibition of growth of $E$. coli by the trypsin treated bacteriocin that was obtained from $L A B$ isolates was investigated by agar well diffusion method (Table 6). The zone of inhibition $(\mathrm{mm})$ in the presence of the trypsin treated bacteriocin from $L A B$ isolates from intestine of $I$. punctatus was reduced, while the one from slurry of fermented $Z$. mays was totally eliminated.

Table 7 describes the biopreservative potential of crude bacteriocins from intestine of $I$. punctatus $(\mathrm{BI})$ and slurry of fermented $Z$. mays (BZ) on juice of ripe orange and Titus fish. The tested samples were initially sterilized in order to eliminate possible contamination before the assessment. There was a reduction in growth of inoculated organism ( $E$. coll) in the orange juice, Titus juice and standard (benzoic acid) compared to control group as the treatment progressed. This was revealed by the reduced values of colony forming units of the indicator (Log CFU/mL) pathogen (Table 7) in all the treatment groups in relation to the control group. The growth inhibition of the pathogen by BZ $(9.96 \pm 0.09 \mathrm{Log}$ $\mathrm{CFU} / \mathrm{mL}$ ) during the six day of the preservation of orange juice was significantly $(p<0.05)$ lower than that of $B$ $(10.96 \pm 0.09 \mathrm{Log} \mathrm{CFU} / \mathrm{mL})$ or standard preservative $(11.70 \pm 0.10 \mathrm{Log} C F U / \mathrm{mL})$ in the treated orange juice (Figure 1a). The preservation of Titus fish was a reversal as there was a significant $(p<0.05)$ decrease in inhibition of the indicator organism as a result of application of $\mathrm{BI}$ $(10.00 \pm 0.10 \mathrm{Log} C F U / \mathrm{mL}$ ) to sample of Titus fish (Figure 1b) as at the last (6th) day of treatment in relation to other groups.

Using agar well diffusion method to access the production of antimicrobial agents by the selected bacterial isolates from the $I$. punctatus intestine and fermented $Z$. mays against three pathogens, the susceptibility of various Gram positive ( $S$. aureus and $B$. subtilis) and Gram negative (E. coli) bacteria to grow in presence of crude extract of bacteriocin revealed 
Table 5. Effect of alteration of $\mathrm{pH}$ on the inhibitory activity of crude bacteriocins from intestine of $l$. punctatus and slurry of fermented $Z$. mays.

\begin{tabular}{lccc}
\hline \multirow{2}{*}{ Indicator organisms } & $\mathbf{p H}$ & \multicolumn{2}{c}{ Zones of inhibition of bacteriocin (mm) } \\
\cline { 3 - 4 } & 2 & Intestine of l. punctatus & Fermented Z. mays \\
\hline \multirow{3}{*}{ E. coli } & $4.30 \pm 0.17$ & $10.10 \pm 0.33$ \\
& 6 & $6.80 \pm 0.19$ & $14.20 \pm 0.12$ \\
& 7 & $14.10 \pm 0.92$ & $19.50 \pm 0.61$ \\
& 9 & $8.50 \pm 0.21$ & $10.30 \pm 0.26$ \\
& & $5.97 \pm 0.19$ & $7.00 \pm 0.09$ \\
S. aureus & 2 & No inhibition & \\
& 4 & No inhibition & $4.30 \pm 0.41$ \\
& 6 & $2.01 \pm 0.08$ & $8.30 \pm 0.39$ \\
& 7 & $3.45 \pm 0.11$ & $10.10 \pm 0.17$ \\
& 9 & No inhibition & $12.00 \pm 1.96$ \\
B. subtilis & & & $11.40 \pm 0.99$ \\
& 2 & $16.00 \pm 1.05$ & \\
& 4 & $26.10 \pm 2.01$ & $1.40 \pm 0.07$ \\
& 6 & $29.60 \pm 0.98$ & $3.60 \pm 0.17$ \\
& 7 & $29.40 \pm 1.01$ & $7.30 \pm 0.11$ \\
& 9 & $20.90 \pm 1.06$ & $5.30 \pm 0.18$ \\
& & & $2.90 \pm 0.21$ \\
\hline
\end{tabular}

Table 6. Effect of trypsin in antimicrobial property of bacteriocins from intestine of $I$. punctatus and slurry of fermented $Z$. mays.

\begin{tabular}{lcccc}
\hline \multirow{3}{*}{ Indicator organisms } & \multicolumn{3}{c}{ Zones of inhibition of the bacteriocins (mm) } \\
\cline { 2 - 5 } & \multicolumn{2}{c}{ Intestine of l. punctatus } & \multicolumn{2}{c}{ Fermented $Z$. mays } \\
\cline { 2 - 5 } & Control & Sample & Control & Sample \\
\hline E. coli & $7.90 \pm 0.43$ & $4.70 \pm 0.05$ & $20.80 \pm 2.01$ & Nil \\
\hline
\end{tabular}

inhibition against $E$. coli, $S$. aureus and $B$. subtilis at varied degrees (Figure 1). There was an evident reduction in the microbial count of pathogenic organisms on application of bacteriocin with little or no effect on the growth of E. coli.

\section{DISCUSSION}

LAB comprise a group of diverse microorganisms that generates lactic acid as the major product during the fermentation process, and are also categorized as Grampositive bacteria that have a number of biotechnological abilities in food industry (Alvarez-Sieiro et al., 2016). LAB produce assorted types of substances that include the metabolic end products, bactericidal or antibiotic-like proteneceous substances that are termed bacteriocins (Klaenhammer, 1988). LAB that associate with food substances are obtained from plant as well as animal origins. The LAB strains are found in milk products, fermented foods, animal intestines or freshwater fishes, soil samples, sugar cane plants, and poultry farms (Barakat et al., 2011). Various types of bacteriocin have been isolated from LAB, for instance: nisin, lacticin and lactosin which are obtained Lactococcus lactis and Lactobacillus sakei (De Vuyst and Vandamme, 1994; Mørtvedt et al., 1991; Piard et al., 1992). Bacteriocins are relevant in different facet of life, especially in maintenance of food safety in order to extend the shelf life of such food through the formation of fermentation products (Sarika et al., 2010).

In this study, MRS medium were used under anaerobic conditions in order to allow the identification of possible LAB isolates from the selected animal and plant tissues. This was in accordance with the recommendation of Ouali et al. (2014) where the MRS medium were recommended for isolation of different micro-organisms. Reports from Pham et al. (2014), Al Kassaa et al. (2014) and Fontana et al. (2013) established that selection of potential probiotic bacteria (LAB strains) requires proper identification of the selected organism through morphological and biochemical tests as the organism 
Table 7. Biopreservative potential of bacteriocins from intestine of $I$. punctatus and slurry of fermented $Z$. mays.

\begin{tabular}{lcccc}
\hline \multirow{2}{*}{ Test food samples } & \multicolumn{4}{c}{ Microbial counts (Log CFU/mL) } \\
\cline { 2 - 5 } & Control & Sample (BI) & Sample (BZ) & Standard \\
\hline Ripe oranges & $5.93 \pm 0.01$ & $5.93 \pm 0.07$ & $5.93 \pm 0.01$ & $5.93 \pm 0.03$ \\
Day 0 & $5.99 \pm 0.04$ & $5.98 \pm 0.03$ & $6.13 \pm 0.02$ & $5.98 \pm 0.03$ \\
Day 1 & $6.13 \pm 0.11$ & $6.10 \pm 0.04$ & $6.16 \pm 0.02$ & $6.17 \pm 0.05$ \\
Day 2 & $7.54 \pm 0.06$ & $7.11 \pm 0.04$ & $7.22 \pm 0.04$ & $7.48 \pm 0.08$ \\
Day 3 & $9.85 \pm 0.09$ & $7.90 \pm 0.08$ & $8.03 \pm 0.06$ & $8.20 \pm 0.07$ \\
Day 4 & $10.17 \pm 0.08$ & $8.93 \pm 0.06$ & $9.95 \pm 0.08$ & $9.78 \pm 0.09$ \\
Day 5 & $14.99 \pm 0.11$ & $9.86 \pm 0.10$ & $10.96 \pm 0.09$ & $11.70 \pm 0.10$ \\
Day 6 & & & & \\
Titus fish & & & & \\
Day 0 & $5.93 \pm 0.03$ & $5.93 \pm 0.02$ & $5.93 \pm 0.01$ & $5.93 \pm 0.03$ \\
Day 1 & $6.29 \pm 0.03$ & $5.98 \pm 0.03$ & $6.02 \pm 0.01$ & $6.19 \pm 0.03$ \\
Day 2 & $7.49 \pm 0.01$ & $6.10 \pm 0.07$ & $6.39 \pm 0.03$ & $7.22 \pm 0.03$ \\
Day 3 & $8.00 \pm 0.10$ & $7.65 \pm 0.03$ & $7.65 \pm 0.06$ & $7.55 \pm 0.04$ \\
Day 4 & $10.30 \pm 0.10$ & $7.94 \pm 0.07$ & $8.03 \pm 0.07$ & $8.11 \pm 0.09$ \\
Day 5 & $12.70 \pm 0.11$ & $9.99 \pm 0.10$ & $10.03 \pm 0.09$ & $10.04 \pm 0.09$ \\
Day 6 & $15.04 \pm 0.13$ & $10.00 \pm 0.10$ & $11.01 \pm 0.09$ & $11.01 \pm 0.08$ \\
\hline
\end{tabular}

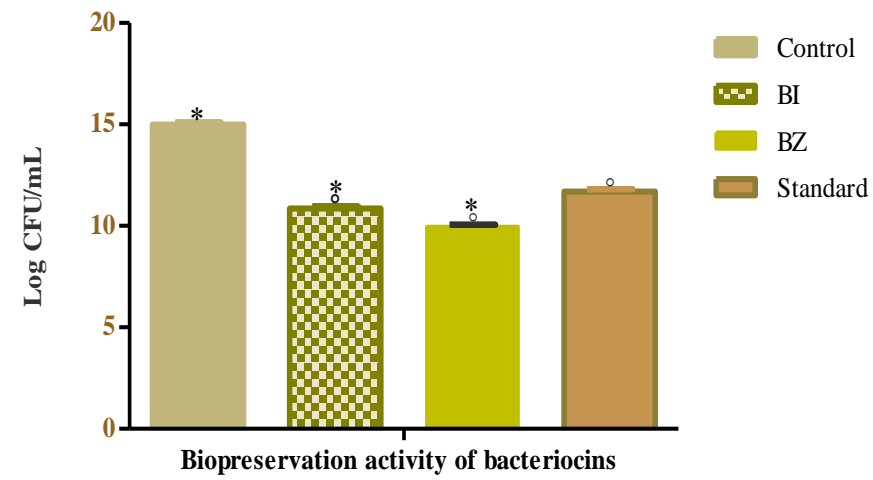

a

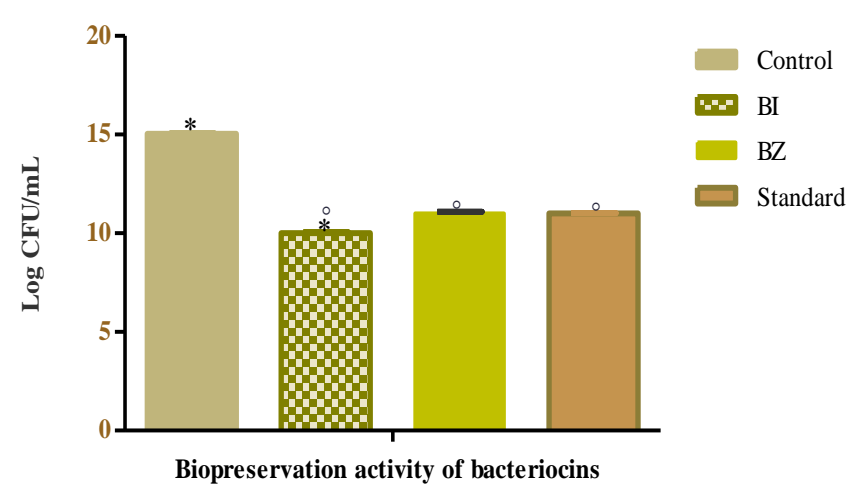

b

Figure 1. Biopreservative activities of bacteriocins from intestine of $I$. punctatus (BI) and slurry of fermented $Z$. mays (BZ) on orange juice (a) and Titus fish (b) as at day 7. All values are presented as Mean \pm Standard Error of Mean of triplicate readings. Comparisons were made between the treatment groups. $\left({ }^{*}\right) p<0.05$ versus Standard (benzoic acid); $\left({ }^{\circ}\right) p<0.05$ versus Control.

shows a bacilli shape, and without catalase activity. A total of the 8 isolates obtained from $I$. punctatus intestine and 7 isolates from slurry of fermented $Z$. mays were confirmed to be Gram positive, catalase negative, oxidase negative, non-spore, and white or cream coloured rod micro-organisms. Previous reports also described $L A B$ as genetically and physiologically distinct set of rod-shaped, Gram-positive and catalase negative bacteria (Ashmaig et al., 2009; Dallal et al., 2017; Guetouache and Guessas, 2015).

Furthermore, the isolates which were able to grow in anaerobic condition displayed an ability to ferment carbohydrates such as glucose, fructose, maltose and lactose as they liberate gas in the culture media. Fermentation of carbohydrates by LAB strains has been reported by Rattanachaikunsopon and Phumkhachorn (2010), Zou et al. (2013) and Jose et al. (2015). Also, there was a production of acid from glucose by these isolates, thereby, suggesting the properties of Lactobacillus species as described by Wang et al. (2010) and $\mathrm{Ni}$ et al. (2015). Previously, LAB have been isolated from both animal and plant sources in a bid to determine their probiotic ability or tendency to liberate antimicrobial substances that can be used in food preservation (Barakat et al., 2011; Tufail et al., 2011). Some of these sources include intestine or gut of fish (Balcázar et al., 
2008; Rao et al., 2015; Ringø et al., 2018; Sica et al., 2012). Fermented food samples including fermented $Z$. mays have also been reported to possess probiotic $L A B$ strains (Onwuakor et al., 2014; Oyedeji et al., 2013; Rao et al., 2015; Zou et al., 2013). The isolated LAB strains produced acid in fermentation broth as an attribute of heterofermenter. Homofermenters are known for production of lactic acid from glucose. Two classes of fermentation strains of LAB (homofermentative and heterofermentative) were previously mentioned by researchers (Akalu et al., 2017; Nigatu et al., 2015). Some of the considerations made in the selection of potential probiotic $L A B$ include optimum growth temperature and effect of salt concentration on their fermentation activities. Table 1 shows that the LAB isolates were stable at relatively high temperature range (10 to $37^{\circ} \mathrm{C}$ ), and can be said to be heat tolerant, therefore the basis for the production of acid in the fermentation broth by the LAB isolates from the increased glycolytic activity. This is an added advantage over thermolabile pathogenic organisms, as the liberated acid reduces the contamination by other microorganisms. The report of this study is in agreement with Qiuju et al. (2013) and Zorriehzahra et al. (2016). The LAB isolates from the two tested samples were osmotolerance at $3 \%$ $\mathrm{NaCl}$, while only the $\mathrm{LAB}$ isolates from intestine of $I$. punctatus could grow in $5 \% \mathrm{NaCl}$ (Table 1). This indicates that the LAB strains from intestine of $l$. punctatus may be more tolerance to osmotic concentrations of $\mathrm{NaCl}$ than the strains from slurry of fermented Z. mays. Van Sinderen and Crowley (2013) and Adnan and Tan (2007) described tolerance of LAB strains to osmotic concentrations of salt like $\mathrm{NaCl}$ as an added advantage to commercial applications. Other scientists have previously reported the ability of $L A B$ strains to withstand osmotic concentration resulting from addition of salts (Subramanyam, 2020; Van Sinderen and Crowley, 2013).

Despite the abundant information on production of bacteriocins from terrestrial origins or $L A B$ that are capable of producing bacteriocins, there have been paucity of information on application of $L A B$ especially in bacteriocins production in $l$. punctatus. Production of bacteriocin by $L A B$ strains is essential factor in the choice of probiotic bacterial strains (Dobson et al., 2012). The bacteriocins which are proteinaceous substances are used to inhibit the growth of related microorganisms, and are recently applied in food preservation. Table 2 shows that the cell free supernatants obtained from culture of LAB strains from intestine of $I$. punctatus and fermented $Z$. mays samples contained proteinaceous substance (suspected to be bacteriocins) with protein concentrations $108.4 \pm 3.9$ and $102.7 \pm 3.0 \mathrm{mg} / \mathrm{mL}$, respectively. This is known as bacteriocins. This is similar to the reports of Udhayashree et al. (2012) and Abbasiliasi et al. (2012).

In a bid to characterize the proteinaceous substance, the antimicrobial activity of the substance was investigated in cultures of E. coli, S. aureus and B. subtilis
(Table 3). The indicator organisms were vulnerable to the activity of the crude bacteriocins at varied degrees. Gram-positive bacteria ( $S$. aureus and $B$. subtilis) responded positively to inhibition of growth by the crude bacteriocins obtained from intestine of $I$. punctatus and $Z$. mays. This is an indication of antibacterial activity of bacteriocins produced by the isolated LAB against the selected pathogens. In the company of these are Gramnegative bacteria ( $E$. coll) whose cell membrane is surrounded by lipid rich cell wall as in the case of any Gram-negative bacteria, but still proved sensitive to antibacterial actions of the extracted bacteriocins. Reports from Tufail et al. (2011) and Sankar et al. (2012) revealed the antibacterial activity of bacteriocin against some pathogenic organisms like E. coli and $S$. aureus. Yang et al. (2012), Djadouni and Kihal (2012) and Gaamouche et al. (2014) reported the antimicrobial activity of LAB bacteriocins in some Gram-positive bacteria. For instance, Afolayan et al. (2017) and Rather et al. (2017) recounted the antimicrobial activity of substance obtained from $L A B$ isolates from fermented $Z$. mays and gut of fishes, respectively. This work supported the tendency of bacteriocins to affect the growth of both Gram-positive and Gram-negative organisms (Abriouel et al., 2011).

The effects of alteration of temperature and $\mathrm{pH}$ on activity of crude bacteriocins from the LAB isolates were determined using $E$. coli, $S$. aureus and $B$. subtilis as indicator organism. The crude bacteriocins were found to be heat stable especially at 37 and $50^{\circ} \mathrm{C}$ for bacteriocins from fermented $Z$. mays and intestine of $I$. punctatus, respectively (Table 4). These results indicate that bacteriocin produced by $\mathrm{LAB}$ from intestine of $l$. punctatus is more heat stable than the fermented $Z$. mays, as its activity was sustained after the heat treatment at the aforementioned temperature. Bacteriocins that are used as food preservative are usually heat stable since preparation of many food requires heat in one way or the other (Ogunbanwo et al., 2003). Previous reports have also corroborated the present finding that the bacteriocins from the $L A B$ isolates are heat stable (Gómez-Sala et al., 2015; Udhayashree et al., 2012).

Effect of $\mathrm{pH}$ on activity of crude bacteriocins from fermented Z. mays and intestine of $I$. punctatus, respectively (Table 5) was carried out. It was observed that bacteriocin produced by $L A B$ in intestine of $l$. punctatus and fermented $Z$. mays were optimally stable at $\mathrm{pH}$ 6. This further confirmed the tolerance of bacteriocins from the $L A B$ to acidic rather than the alkaline $\mathrm{pH}$ values and that they can be applied in acidic foods (Adesina et al., 2016; Ayed et al., 2015; Li et al., 2015).

Exposure of $\mathrm{E}$. coli to the trypsin treated bacteriocin that were obtained from $L A B$ isolates showed that zone of inhibition $(\mathrm{mm})$ in the presence of the trypsin treated bacteriocin from $L A B$ isolates from intestine of $l$. punctatus was reduced, while the one from slurry of 
fermented Z. mays was totally eliminated (Table 6). This indicates that crude bacteriocins were inactivated by treatment with trypsin as a result of reduction or elimination of antimicrobial activity when it relates to controls, and further established the antimicrobial substances obtained from the isolated $L A B$ cultures to be bacteriocin; a proteinaceous substance (Sankar et al., 2012).

Biopreservation is a potent natural method of extension of shelf life and safety of foods by using naturally occurring microorganisms, their innate antibacterial agents of specified quality and quantity (Ghanbari et al., 2013). Biopreservative activity of bacteriocin from $L A B$ has been of utmost interest in the recent time. The reduction of microbial population in Titus fish and orange juice after addition of the crude protein-like substances produced from intestine of $I$. punctatus and $Z$. mays (Table 7) shows that the bacteriocins can be applied in preservation of food from plant and animal origins. The result also revealed that bacteriocin obtained from $L A B$ in intestine of $I$. punctatus is more efficient in Titus fish than bacteriocin from $Z$. mays. Reduction of bacterial counts in food samples after treatment with crude bacteriocins as a measure of preservation has been documented. GómezSala et al. (2016), Ghanbari et al. (2013) and Sarika et al. (2019) observed the extension of shelf life of fish after treatment with bacteriocins. Similarly, Udhayashree et al. (2012) and Ageni et al. (2017) reported a decrease in microbial loads in edible milk and button mushrooms, and in fermented maize (Ogi) and cassava (Fufu), respectively, In addition, bacteriocins from $L A B$ obtained from these food items are efficient in the preservation of the selected test food samples, the crude bacteriocin from fish intestine (BI) was more efficient in Titus fish than in orange juice than the chemical preservative.

\section{Conclusion}

The present study revealed that the protein-like antibacterial substances from LAB isolates obtained in the samples of $I$. punctatus (Cat fish) and slurry fermented Z. mays (Ogi) possess an extensive spectrum of inhibitory activity against $S$. aureus and $B$. subtilis. The reduction in the microbial load in Titus fish and Orange juice exhibited by these proteinaceous substances (crude bacteriocins) also justify their tendency to preserve sea foods and fruits.

\section{CONFLICT OF INTERESTS}

The authors have not declared any conflict of interests.

\section{ACKNOWLEDGEMENTS}

The authors thank the management of Lagos State
Polytechnic and the entire members of staff of Chemical Science and Biological Science Departments for their supports throughout the study.

\section{REFERENCES}

Abbasiliasi S, Tan JS, Ibrahim TAT, Ramanan RN, Vakhshiteh F, Mustafa S, Ariff AB (2012). Isolation of Pediococcus acidilactici Kp10 with ability to secrete bacteriocin-like inhibitory substance from milk products for applications in food industry. BMC Microbiology 12(1):260.

Abriouel H, Franz C, Omar NB, Gálvez A (2011). Diversity and applications of Bacillus bacteriocins. FEMS Microbiology Reviews 35(1):201-232.

Adesina I, Ojokoh A, Arotupin D (2016). Effect of bacteriocinogenic Pediococcus pentosaceus 101 strain and its bacteriocin on growth performance and intestinal microbiota of albino rat. Microbiology Research Journal International. https://www.researchgate.net/publication/297663001_Effect_of_Bact eriocinogenic_Pediococcus_pentosaceus_IO1_Strain_and_Its_Bacte riocin_on_Growth_Performance_and_Intestinal_Microbiota_of_Albino Rat

Adesokan I, Abiola O, Ogundiya M (2010). Influence of ginger on sensory properties and shelf-life of Ogi, a Nigerian traditional fermented food. African Journal of Biotechnology 9(12).

Adnan AFM, Tan IK (2007). Isolation of lactic acid bacteria from Malaysian foods and assessment of the isolates for industrial potential. Bioresource Technology 98(7):1380-1385

Afolayan AO, Ayeni FA, Ruppitsch W (2017). Antagonistic and quantitative assessment of indigenous lactic acid bacteria in different varieties of ogi against gastrointestinal pathogens. The Pan African Medical Journal 27

Ageni L, Ajibade G, Yerima B, Appah J (2017). Shelf life extension study of ogi and fufu using bacteriocin isolated from Lactobacillus acidophilus of fermented dairy products. African Journal of Microbiology Research 11(32):1286-1293.

Akalu N, Assefa F, Dessalegn A (2017). In vitro evaluation of lactic acid bacteria isolated from traditional fermented Shamita and Kocho for their desirable characteristics as probiotics. African Journal of Biotechnology 16(12):594-606.

Al Kassaa I, Hamze M, Hober D, Chihib NE, Drider D (2014). Identification of vaginal lactobacilli with potential probiotic properties isolated from women in North Lebanon. Microbial Ecology 67(3):722734.

Ali AA (2010). Beneficial role of lactic acid bacteria in food preservation and human health: a review. Research Journal of Microbiology 5(12):1213-1221.

Alka S, Neelam Y, Shruti $S$ (2012). Effect of fermentation on physicochemical properties and in vitro starch and protein digestibility of selected cereals. International Journal of Agricultural and Food Science 2(3):66-70.

Alvarez-Sieiro P, Montalbán-López M, Mu D, Kuipers OP (2016). Bacteriocins of lactic acid bacteria: extending the family. Applied Microbiology and Biotechnology 100(7):2939-2951.

Ashmaig A, Hasan A, El Gaali E (2009). Identification of lactic acid bacteria isolated from traditional Sudanese fermented camel's milk (Gariss). African Journal of Microbiology Research 3(8):451-457.

Ayed HB, Maalej H, Hmidet N, Nasri M (2015). Isolation and biochemical characterisation of a bacteriocin-like substance produced by Bacillus amyloliquefaciens An6. Journal of Global Antimicrobial Resistance 3(4):255-261.

Balcázar JL, Vendrell D, de Blas I, Ruiz-Zarzuela I, Muzquiz JL, Girones O (2008). Characterization of probiotic properties of lactic acid bacteria isolated from intestinal microbiota of fish. Aquaculture 278(14):188-191.

Barakat OS, Ibrahim G, Tawfik N, El-Kholy W, EI-Rab GD (2011). Identification and probiotic characteristics of Lactobacillus strains isolated from traditional Domiati cheese. International Journal of Microbiology Research 3(1):59.

Barbosa AAT, Mantovani HC, Jain S (2017). Bacteriocins from lactic 
acid bacteria and their potential in the preservation of fruit products. Critical Reviews in Biotechnology 37(7):852-864.

Behnsen J, Deriu E, Sassone-Corsi M, Raffatellu M (2013). Probiotics: properties, examples, and specific applications. Cold Spring Harbor Perspectives in Medicine 3(3):a010074.

Chang JY, Chang HC (2010). Improvements in the quality and shelf life of kimchi by fermentation with the induced bacteriocin-producing strain, Leuconostoc citreum GJ7 as a starter. Journal of Food Science 75(2):M103-M110.

Dallal MS, Zamaniahari S, Davoodabadi A, Hosseini M, Rajabi Z (2017) Identification and characterization of probiotic lactic acid bacteria isolated from traditional persian pickled vegetables. GMS Hygiene and Infection Control 12

Davidson PM, Taylor TM, Schmidt SE (2012). Chemical preservatives and natural antimicrobial compounds. Food Microbiology: Fundamentals and Frontiers pp. 765-801.

De Vuyst L, Leroy F (2007). Bacteriocins from lactic acid bacteria: production, purification, and food applications. Journal of Molecular Microbiology and Biotechnology 13(4):194-199.

De Vuyst L, Vandamme EJ (1994). Nisin, a lantibiotic produced by Lactococcus lactis subsp. lactis: properties, biosynthesis, fermentation and applications. Bacteriocins of Lactic Acid Bacteria. pp. 151-221.

Deegan LH, Cotter PD, Hill C, Ross P (2006). Bacteriocins: biological tools for bio-preservation and shelf-life extension. International Dairy Journal 16(9):1058-1071.

Del Nobile MA, Lucera A, Costa C, Conte A (2012). Food applications of natural antimicrobial compounds. Frontiers in Microbiology 3:287.

Djadouni F, Kihal M (2012). Antimicrobial activity of lactic acid bacteria and the spectrum of their biopeptides against spoiling germs in foods. Brazilian Archives of Biology and Technology 55(3):435-444.

Du Toit M, Engelbrecht L, Lerm E, Krieger-Weber S (2011). Lactobacillus: the next generation of malolactic fermentation starter cultures-an overview. Food and Bioprocess Technology 4(6):876906.

Ejigui J, Savoie L, Marin J, Desrosiers T (2005). Beneficial changes and drawbacks of a traditional fermentation process on chemical composition and antinutritional factors of yellow maize (Z. mays). Journal of Biological Sciences 5(5):590-596.

Eun JB, Chung HJ, Hearnsberger J (1994). Chemical composition and microflora of channel catfish (Ictalurus punctatus) roe and swim bladder. Journal of Agricultural and Food Chemistry 42(3):714-717.

Farkas J (2007). Physical methods of food preservation Food Microbiology: Fundamentals and Frontiers. Third Edition American Society of Microbiology pp. 685-712.

Fontana L, Bermudez-Brito M, Plaza-Diaz J, Munoz-Quezada S, Gil A (2013). Sources, isolation, characterisation and evaluation of probiotics British. Journal of Nutrition 109(S2):S35-S50.

Gaamouche S, Arakrak A, Bakkal M, LaglaouiA (2014). Antimicrobial activity of lactic acid bacteria and bacteriocins isolated from a traditional brine table olives against pathogenic bacteria. International Journal of Current Microbiology and Applied Science 3(11):657-666.

Ghanbari M, Jami M, Domig KJ, Kneifel W (2013). Seafood biopreservation by lactic acid bacteria-a review. LWT-Food Science and Technology 54(2):315-324.

Gómez-Sala B, Herranz C, Díaz-Freitas B, Hernánde PE, Sal A, Cintas LM (2016). Strategies to increase the hygienic and economic value of fresh fish: Biopreservation using lactic acid bacteria of marine origin. International Journal of Food Microbiology 223:41-49.

Gómez-Sala B, Muñoz-Atienza E, Sánchez J, Basanta A, Herranz C, Hernández PE, Cintas LM (2015). Bacteriocin production by lactic acid bacteria isolated from fish, seafood and fish products. European Food Research and Technology 241(3):341-356.

Gould GW (2012). New methods of food preservation: Springer Science and Business Media.

Guetouache M, Guessas B (2015). Characterization and identification of lactic acid bacteria isolated from traditional cheese (Klila) prepared from cow's milk. African Journal of Microbiology Research 9(2):71-77.

Hanim C (2017). Effect of $\mathrm{pH}$ and Temperature on Bacillus subtilis FNCC 0059 oxalate decarboxylase activity. Pakistan Journal of Biological Sciences-20(9):436-441.

ljarotimi SO, Keshinro OO (2011). Determination of amino acid, fatty acid, mineral, functional and choking properties of germinated and fermented popcorn ( $Z$. mays everta) flour. European Journal of Nutrition and Food Safety pp. 102-122.

Jose NM, Bunt CR, Hussain MA (2015). Comparison of microbiological and probiotic characteristics of lactobacilli isolates from dairy food products and animal rumen contents. Microorganisms 3(2):198-212.

Klaenhammer TR (1988). Bacteriocins of lactic acid bacteria. Biochimie 70(3):337-349.

Kozaki M, Uchimura T, Okada S (1992). Experimental manual of lactic acid bacteria. Tokyo, Japan: Asakurasyoten pp. 34-37.

Lee HJ, Kim HJ (2011). Lantibiotics, class I bacteriocins from the genus Bacillus. Journal of Microbiology and Biotechnology 21(3):229-235.

Li D, Ni K, Pang H, Wang Y, Cai Y, Jin Q (2015). Identification and antimicrobial activity detection of lactic acid bacteria isolated from corn stover silage. Asian-Australasian Journal of Animal Sciences 28(5):620.

Liu W, Pang H, Zhang H, Cai $Y$ (2014). Biodiversity of lactic acid bacteria. Springer pp. 103-203

Lück E (1985). Chemical preservation of food. Zentralblatt fur Bakteriologie, Mikrobiologie und Hygiene. 1. Abt. Originale B, Hygiene 180(2-3): 311-318.

Mørtvedt C, Nissen-Meyer J, Sletten K, Nes I (1991). Purification and amino acid sequence of lactocin $\mathrm{S}$, a bacteriocin produced by Lactobacillus sake L45. Applied and Environmental Microbiology 57(6):1829-1834

Ni K, Wang Y, Li D, Cai Y, Pang H (2015). Characterization, identification and application of lactic acid bacteria isolated from forage paddy rice silage PloS one 10(3):e0121967.

Nigatu JM, Tuji FA, Tefera AT (2015). Evaluation of the antagonistic effect of six mixed cultures of lactic acid bacteria, isolated from the Ethiopian fermented milk ergo, against some foodborne pathogens inoculated into the Ethiopian cottage cheese ayib. African Journal of Microbiology Research 9(29):1789-1797.

Noor R, Islam Z, Munshi SK, Rahman F (2013). Influence of temperature on Escherichia coli growth in different culture media. Journal of Pure and Applied Microbiology 7(2): 899-904.

Ogodo A, Ugbogu O, Onyeagba R, Orji F (2017). Dynamics of functional properties of sorghum flours fermented with lactic acid bacteria (LAB)-consortium isolated from cereals. Food Research Journal 24(6):2666-2671

Ogunbanwo S, Sanni A, Onilude A (2003). Characterization of bacteriocin produced by Lactobacillus plantarum $\mathrm{F} 1$ and Lactobacillus brevis OG1. African Journal of Biotechnology 2(8):219-227.

Onwuakor C, Nwaugo V, Nnadi, Emetole J (2014). Effect of varied culture conditions on crude supernatant (bacteriocin) production from four Lactobacillus species isolated from locally fermented maize (ogi) American Journal of Microbiological Research 2(5):125-130.

Ouali FA, AI Kassaa I, Cudennec B, Abdallah M, Bendali F, Sadoun D, Chihib NE, Drider D (2014). Identification of lactobacilli with inhibitory effect on biofilm formation by pathogenic bacteria on stainless steel surfaces. International Journal of Food Microbiology 191:116-124.

Oyedeji O, Ogunbanwo ST, Onilude AA (2013). Predominant lactic acid bacteria involved in the traditional fermentation of fufu and ogi, two Nigerian fermented food products. Food and Nutrition Sciences 4(11):40.

Perez $\mathrm{RH}$, Zendo T, Sonomoto K (2014). Novel bacteriocins from lactic acid bacteria $(\mathrm{LAB})$ : various structures and applications. Microbial Cell Factories 13(1):S3. doi:10.1186/1475-2859-13-S1-S3

Pham D, Ansquer D, Chevalier A, Dauga C, Peyramale A, Wabete N, Labreuche $Y$ (2014). Selection and characterization of potential probiotic bacteria for Litopenaeus stylirostris shrimp hatcheries in New Caledonia. Aquaculture 432:475-482.

Piard JC, Muriana P, Desmazeaud M, Klaenhammer T (1992). Purification and partial characterization of lacticin 481, a lanthioninecontaining bacteriocin produced by Lactococcus lactis subsp. lactis CNRZ 481. Applied and Environmental Microbiology 58(1):279-284.

Piper P, Calderon CO, Hatzixanthis K, Mollapour M (2001). Weak acid adaptation: the stress response that confers yeasts with resistance to organic acid food preservatives. Microbiology 147(10):2635-42.

Pratush A, Gupta A, Kumar A, Vyas G (2012). Application of purified bacteriocin produced by Lactococcus lactis AP2 as food biopreservative in acidic foods. Annals, Food Science Technology 
13:82-87.

Qiuju W, Yizhe C, Shengjun L, Ruijin Z (2013). Isolation and identification of lactic acid bacteria in duodenum of laying hens fed in cage. Journal of Heilongjiang Bayi Agricultural University 3:8.

Ramu R, Shirahatti PS, Devi AT, Prasad A (2015). Bacteriocins and their applications in food preservation. Critical Reviews in Food Science and Nutrition 00-00.

Rao KP, Chennappa G, Suraj U, Nagaraja H, Raj AC, Sreenivasa M (2015). Probiotic potential of Lactobacillus strains isolated from sorghum-based traditional fermented food. Probiotics and Antimicrobial Proteins 7(2):146-156.

Rather IA, Galope R, Bajpai VK, Lim J, Paek WK, Park YH (2017). Diversity of marine bacteria and their bacteriocins: applications in aquaculture. Reviews in Fisheries Science and Aquaculture 25(4):257-269.

Rattanachaikunsopon P, Phumkhachorn P (2010). Lactic acid bacteria: their antimicrobial compounds and their uses in food production Annals of Biological Research 1(4):218-228.

Lowry OH, Rosebrough NJ, Farr AL, Randall RJ (1951). Protein measurement with the Folin phenol reagent. Journal of Biological Chemistry 193:265-275.

Reis JA, Paula AT, Casarotti SN, Penna ALB (2012). Lactic acid bacteria antimicrobial compounds: characteristics and applications. Food Engineering Reviews 4(2):124-140. doi:10.1007/s12393-0129051-2

Ringø E , Gatesoupe FJ (1998). Lactic acid bacteria in fish: a review. Aquaculture 160(3-4):177-203.

Ringø E, Hoseinifar SH, Ghosh K, Doan HV, Beck BR, Song SK (2018). Lactic acid bacteria in finfish-An update. Frontiers in Microbiology 9:1818.

Sankar NR, Priyanka VD, Reddy PS, Rajanikanth P, Kumar VK, Indira $M$ (2012). Purification and characterization of bacteriocin produced by Lactobacillus plantarum isolated from cow milk. International Journal of Microbiology Research 3(2):133-137.

Sarika A, Lipton A, Aishwarya M (2010). Bacteriocin production by a new isolate of Lactobacillus rhamnosus GP1 under different culture conditions. Advance Journal of Food Science and Technololgy 2(5):291-297.

Sarika A, Lipton AP, Aishwarya M (2019). Biopreservative efficacy of bacteriocin GP1 of Lactobacillus rhamnosus GP1 on stored fish filets. Frontiers in Nutrition 6:29.

Shahid M, Hussain B, Riaz D, Khurshid M, Ismail M, Tariq M (2017). Identification and partial characterization of potential probiotic lactic acid bacteria in freshwater Labeo rohita and Cirrhinus mrigala. Aquaculture Research 48(4):1688-1698.

Shahidi F (2015). Handbook of antioxidants for food preservation: Woodhead Publishing.

Sharma S (2015). Food preservatives and their harmful effects. International Journal of Scientific and Research Publications 5(4):1-2.

Sica MG, Brugnoni LI, Marucci PL, Cubitto MA (2012). Characterization of probiotic properties of lactic acid bacteria isolated from an estuarine environment for application in rainbow trout (Oncorhynchus mykiss, Walbaum) farming. Antonie van Leeuwenhoek 101(4):869879.

Silva CC, Silva SP, Ribeiro SC (2018). Application of bacteriocins and protective cultures in dairy food preservation. Frontiers in Microbiology 9:594.

Smid E, Kleerebezem M (2014). Production of aroma compounds in lactic fermentations. Annual Review of Food Science and Technology 5:313-326.

Stewart CM (2003). Staphylococcus aureus and staphylococcal enterotoxins. Ch 12 In: Hocking AD (ed) Foodborne microorganisms of public health significance. 6th ed, Australian Institute of Food Science and Technology (NSW Branch) Sydney pp. 359-380.

Subramanyam MN (2020). Molecular characterisation of probiotic Lactobacillus fermentum isolated from home made curd Journal of Microbiology, Biotechnology and Food Sciences 9(4):848-855.
Trząskowska M, Kołożyn-Krajewska D, WójciakK, Dolatowski Z (2014). Microbiological quality of raw-fermented sausages with Lactobacillus casei LOCK 0900 probiotic strain. Food Control 35(1):184-191.

Tserovska L, Stefanova S, Yordanova T (2002). Identification of lactic acid bacteria isolated from Katyk, goat's milk and Cheese. Journal of Culture Collections 3:48-52.

Tufail M, Hussain S, Malik F, Mirza T, Parveen G, Shafaat S, Sadiq A (2011). Isolation and evaluation of antibacterial activity of bacteriocin produced by Lactobacillus bulgaricus from yogurt. African Journal of Microbiology Research 5(22):3842-3847.

Udhayashree N, Senbagam D, Senthilkumar B, Nithya K, Gurusamy R (2012). Production of bacteriocin and their application in food products Asian Pacific Journal of Tropical Biomedicine 2(1):S406S410.

Van Sinderen D, Crowley S (2013). Lactobacillus plantarum species possessing broad spectrum anti-fungal activity and exhibiting high heat tolerance and osmotolerance: Google Patents.

Vignolo G, Saavedra L, Sesma F, Raya R (2012). 22 Food bioprotection: lactic acid bacteria as natural preservatives. Progress in Food Preservation P 453.

Wang CY, Lin PR, Ng CC, Shyu YT (2010). Probiotic properties of Lactobacillus strains isolated from the feces of breast-fed infants and Taiwanese pickled cabbage. Anaerobe 16(6):578-585.

Woraprayote W, Malila Y, Sorapukdee S, Swetwiwathana A, Benjakul S, Visessanguan W (2016). Bacteriocins from lactic acid bacteria and their applications in meat and meat products. Meat Science 120:118132.

Yang E, Fan L, Jiang Y, Doucette C, Fillmore S (2012). Antimicrobial activity of bacteriocin-producing lactic acid bacteria isolated from cheeses and yogurts. AMB Express 2(1):48.

Yang SC, Lin CH, Sung CT, Fang JY (2014). Antibacterial activities of bacteriocins: application in foods and pharmaceuticals. Frontiers in Microbiology 5:241.

Yousef AE, Balasubramaniam V (2013). Physical methods of food preservation. Food Microbiology American Society of Microbiology pp. 737-763.

Zorriehzahra MJ, Delshad ST, Adel M, Tiwari R, Karthik K, Dhama K, Lazado CC (2016). Probiotics as beneficial microbes in aquaculture: an update on their multiple modes of action: a review. Veterinary Quarterly 36(4):228-241.

Zou Y, Liu F, Fang C, Wan D, Yang R, Su Q, Zhao J (2013). Lactobacillus shenzhenensis sp. nov., isolated from a fermented dairy beverage. International Journal of Systematic and Evolutionary Microbiology 63(5):1817-1823. 